\title{
PANDANGAN ORIENTALIS TERHADAP SEJARAH ISLAM AWAL
}

\author{
Rizki Ulfahadi, ${ }^{1}$ Reynaldi Adi Surya ${ }^{2}$ \\ ${ }^{1}$ MAPK Koto Baru Padang Panjang \\ Padang Panjang, Sumatera Barat, Indonesia \\ ${ }^{2}$ SMK Voctech 1 Tangerang \\ Kota Tangerang, Banten, Indonesia \\ hadir1501@gmail.com
}

\begin{abstract}
Abstrak:
Studi Islam di Barat memiliki perbedaan metode dan sudut pandang yang berbeda dengan pola studi Islam di dunia belahan Timur (seperti Arab atau Indonesia). Orientalis meneliti agama Islam melalui kacamata historis dan kritis. Tulisan ini mengangkat mengenai masalah "Islam Awal" atau "Islam Lama”, yaitu penelitian tentang kelahiran agama Islam, asal usul Nabi Muhammad, asal kata "Islam" dan lain sebagainya. Tulisan ini memaparkan pandangan orientalis tentang konstruksi sarjana Muslim tentang Islam awal.
\end{abstract}

Kata Kunci: Orientalis, Islam Awal, Studi Islam

\begin{abstract}
:
Islamic Studies in the Western have different view and method from Eastern Islamic studies (such as Arab or Indonesia). The orientalists researched Islam through critical and historical views. One of the topics discussed in this paper is "Early Islam" or "Old Islam" problem, the origin of prophet Muhammad SAW, the origin of the word "Islam", and etc. We explain their opinions about Muslim scholars' construction of the early Islam.
\end{abstract}

Keywords: Orientalist, Early Islam, Islamic Studies. 


\section{Pendahuluan}

Kata orientalisme berasal dari kata "orient" yang sederhananya berarti timur. ${ }^{1}$ Kata lainnya yang sering dinisbatkan kepada orientalisme adalah "oriental" yang memiliki arti berkaitan atau terletak di timur. Timur dalam artian letak geografis yang meliputi Asia dari Himalaya dan Semenanjung Malaya di sebelah barat wallace. ${ }^{2}$ Sedangkan dalam Kamus Besar Bahasa Indonesia (KBBI), orientalisme dimaknai sebagai sebuah ilmu pengetahuan tentang ketimuran atau tentang budaya ketimuran. ${ }^{3}$

Pemaknaan secara istilah terhadap kata orientalisme akan ditemukan variasi apabila melihat pendapat-pendapat para tokoh. Dalam buku berjudul "Buhüth Fì at-Tabshīr Wa al-Istishrāq" (Pembahasan Tentang Misionarisme dan Orientalisme) karangan Hasan Abdur Rauf, disebutkan bahwa kata "orientalisme" secara umum menunjukkan aktivitas orang-orang non-Arab khususnya ilmuwan Barat yang mempelajari ilmu-ilmu tentang ketimuran, baik itu dari segi bahasa, agama, sejarah, kebiasaan, peradaban, dan adat istiadatnya. Khususnya orang-orang yang mempelajari tentang dunia Arab, China, Persia dan India.

Perkembangan "orientalisme" selanjutnya, kata ini identik ditujukan kepada orang-orang Kristen yang melakukan studi terhadap Islam dan bahasa Arab. ${ }^{4}$ Kemudian ada pula pendapat yang lebih umum, yaitu menurut Affaf Sabrah yang mengatakan oritentalisme adalah istilah yang luas yang meliputi semua kegiatan kelompok-kelompok yang melakukan studi-studi ketimuran, baik ilmu pengetahuan, seni, sastra, agama dan sejarah. ${ }^{5}$ Salah satu objek kajian para orientalis adalah tentang makna dan sejarah Islam. Makna dan sejarah tentang Islam yang dikaji dan ditulis oleh para orientalis ini menimbulkan kontoversi di kalangan akademisi Islam. Berangkat dari problem itulah, tulisan ini akan mencoba memaparkan dan menjabarkan dengan analisis-deskriptif guna mendapatkan pemahaman yang komprehensif tentang bagaimana makna sesungguhnya dari orientalisme serta bagaimana pandangannya tentang sejarah Islam. Semoga dengan hadirnya tulisan ini dapat menjadi khazanah rujukan baru dalam pemikiran Islam kontemporer.

${ }^{1}$ Hasani Ahmad Said, "Potret Studi al-Qur'an di Mata Orientalis," Jurnal At-Tibyan 3, no. 1 (2018): 25.

2 Muhammad Bahar Akkase, "Orientalis dan Orientalisme Dalam Perspektif Sejarah,”Jurnal Ilmu Budaya 4, no. 1 (2016): 51.

${ }^{3}$ Ahli bahasa, kesusasteraan dan kebudayaan bangsa-bangsa Timur (Asia). Lukman Ali dkk., Kamus Besar Bahasa Indonesia (KBBI) Edisi Kedua (Jakarta: Departemen Pendidikan dan Kebudayaan Balai Pustaka, 1993), 70.

${ }^{4}$ Muhammad Bahar Akkase, "Orientalis dan Orientalisme Dalam Perspektif Sejarah," Jurnal Ilmu Budaya 4, no.1(2016): 51.

${ }^{5}$ Susmihara, "Sejarah Perkembangan Orientalis,"Jurnal Rihlah 5, no. 1 (2017): 43. 


\section{Orientalisme dalam Timbangan}

Tokoh Edward W. Said tidak bisa ditinggalkan apabila membahas soal orientalisme secara akademis. Ia lah yang pertama kali membahas "orientalisme" secara komprehensif dalam bukunya yaitu Orientalism: Western Conceptions of the Orient. Dalam buku tersebut, Said mengatakan, bahwa pelaku orientalisme atau biasa disebut orientalis adalah siapa saja yang mengajar, menulis, atau melakukan penelitian tentang dunia Timur. Adapun 'orientalisme' adalah suatu gaya berpikir bipolar yang membagi dunia ke dalam dua bagian, yaitu "Timur" dan "Barat" yang berfungsi sebagai pranata-pranata hukum untuk menghadapi Timur, yang berkepentingan membuat pernyataan tentang Timur, membenarkan pandangan-pandangan tentang Timur, mendeskripsikannya, dengan mengajarkannya, memposisikannya, menguasainya: pendeknya, Orientalisme adalah cara Barat untuk mendominasi, menata kembali, dan menguasai Timur". ${ }^{6}$ Memang dalam catatan awal sejarahnya, orientalisme adalah produk dari intelektual barat (terutama Eropa) untuk mengkaji timur tetapi sarat akan kepentingan politis misi kekuasaan imperialis untuk menaklukkan Timur.

Pendapat lainnya, ada juga yang mengatakan orientalisme adalah kata yang dinisbatkan kepada sebuah penelitian yang dilakukan oleh orang Barat terhadap berbagai disiplin ilmu ketimuran, baik bahasa, agama, sejarah dan permasalahan-permasalahan sosio-kultural bangsa timur. Atau, ada juga yang mengatakan orientalisme adalah suatu disiplin ilmu yang membahas tentang ketimuran. ${ }^{7}$ Jika dicermati dari banyak pendapat tersebut, hampir semuanya menuju kepada maksud yang sama walau dengan redaksi yang berbeda. Bahwa orientalisme adalah aktivitas penyelidikan atau keilmuan yang dilakukan oleh orang Barat terhadap dunia Timur dalam berbagai aspeknya, termasuk yang paling mencolok adalah agama'. Pada awalnya bisa disepakati definisi orientalisme begitu, namun dalam perjalanan sejarahnya definisi ini sedikit bergeser. Bahkan Najb al-'Aqqy mencantumkan dalam bukunya tokoh Fazlurrahman, seorang cendikiawan Muslim Pakistan, sebagai salah seorang orientalis. ${ }^{8}$ Sehingga, orientalisme bisa juga dipahami sebagai paham yang mengkaji dunia ketimuran dalam berbagai aspeknya dengan menggunakan metode kerangka berpikir Barat yang ilmiah.

Orientalisme pada mulanya berkembang untuk menopang kolonialisasi Barat terhadap bangsa-bangsa di belahan timur. Untuk memperkokoh kekuasaan

${ }^{6}$ Rohanda dan Dian Nuurachman, "Orientalisme vs Oksidentalisme: Benturan dan Dialogisme Budaya Global,” Jurnal Lektur Keagamaan 15, no. 2 (2017): 380.

${ }^{7}$ Muhammad Bahar Akkase, "Orientalis dan Orientalisme Dalam Perspektif Sejarah," Jurnal Ilmu Budaya 4, no. 1 (2016): 51.

${ }^{8}$ Susmihara, "Sejarah Perkembangan Orientalis," Jurnal Rihlah 5, no. 1 (2017): 44. 
mereka dan meredam gejolak serta konflik, para akademisi atau orientalis dikerahkan untuk mempelajari dan mendalami seluk beluk bangsa-bangsa Asia dan Timur Tengah. Mereka mempelajari adat istiadat, budaya, tradisi, norma, karya seni, prilaku, agama, ras, bahkan hingga geografinya. Dari sini banyak tokoh Muslim yang mencurigai orientalisme sebagai produk Barat untuk menghancurkan Islam. orientalis hadir sebagai sebuah studi yang penuh dengan "dendam" dan kebencian terhadap bangsa Timur, khususnya Islam. Kekalahan Barat terhadap Islam dalam Perang Salib, dianggap sebagai awal mula lahirnya gerakan kolonialisasi atau penjajahan yang bersamaan dengan lahirnya orientalisme. Banyaknya teori-teori yang dikemukakan oleh para orientalis cenderung negatif dan berlawanan dengan keyakinan umat Islam, ini yang membuat umat Islam semakin mencurigai dan menuduh orientalis dan orientalisme sebagai upaya untuk merusak Islam. ${ }^{9}$

Pandangan bahwa orientalisme adalah suatu ilmu konspirasi yang bermuatan negatif banyak dianut oleh akademisi Muslim baik luar dan dalam negeri, Sayyid Qutb, Dr. Muhammad al-Bahy, dan Abdul Majid Abdussalam Al-Muhasib penulis buku Ittijāhāt at-Tafsìr Fì al-Assri ar-Rahin yng mengatakan bahwa kemunduran Islam dan kekhalifahan Turki karena masuknya pengaruh barat. ${ }^{10}$ Di Indonesia, tokoh Muslim yang paling gencar menolak orientalisme salah satunya adalah Adian Husaini yang rajin menulis tentang penolakan terhadap ide orientalisme dan Islam liberal.

Namun pandangan yang terlampau negatif dan penuh kecurigaan terhadap Barat dan orientalisme, justru seolah menjadi suatu paranoia alias ketakutan atau suatu kecurigaan yang berlebih-lebihan hingga mendekati tidak masuk akal. Al Makin berkata bahwa pandangan akademisi dan ulama Islam yang mengatakan bahwa Barat berkomplot untuk memerangi Islam, sama sekali tidak mempunyai landasan bukti yang mendasar. Barat bukanlah suatu negara yang utuh, bukan kekuatan tunggal yang berpikiran monolitik atau seirama. tidak semua yang berbau Barat pasti negatif terhadap Islam, dan tidak berarti semua orang Barat membenci Islam. ${ }^{11}$

Pada abad ke-19 dan 20 orientalisme yang pada awalnya dipayungi oleh kolonialisme menjadi semakin menjauh dari tujuan kolonialisasi dan semakin independen. Dengan semangat dan otoritas akademis, orientalisme menjadi suatu pemahaman yang mengkaji berbagai tradisi dan literatur Timur secara

9 Rendra Khaldun,"Telaah Historis Perkembangan Orientalisme Abad XVI-XX," Jurnal Ulumuna 11, no.1 (2007):8-9.

10 Abdul Majid Abdussalam Al-Muhasib, Visi dan Paradigma Al-Qur 'an Kontemporer, terj. M. Maghfur Wachid (Bangil: Al-Izzah, 1997), 6.

${ }^{11}$ Al Makin, Antara Barat dan Timur: Batasan, Dominasi, Relasi, dan Globalisasi (Jakarta: Serambi: 2015), 62. 
objektif dan ilmiah. Hal ini pernah dikatakan oleh Bernard Lewis dan Montgomery Watt yang menyatakan bahwa usaha-usaha para orientalis untuk mengeksplorasi pengetahuan tentang Timur selalu muncul dari rasa ingin tahu intelektual. Lebih mengejutkan lagi sekaligus mengingatkan, Karel A. Steenbrink menyayangkan kalau hambatan-hambatan mental kaum Muslim tidak segera diatasi mereka tidak akan bisa menikmati prestasi-prestasi akademis dari para orientalis. ${ }^{12}$ Mental yang dimaksudkan oleh Steenbrink adalah ketidaksukaan atau kebencian dari kaum Muslim terhadap para orientalis yang dianggap sebagai antek penjajah yang mengakibatkan menutup mata terhadap hasil karya mereka yang telah hadir sebagai produk ilmiah akademis yang seharusnya sangat patut dikaji dan dipelajari.

Namun karena orientalisme mendasari studi mereka deengan catatan kritis juga menolak segala macam kemapanan yang bersifat dogmatis, kadang pendapat dan teori yang dikemukakan oleh orientalis dalam kajian studi Islam, cenderung ganjil dan bertentangan dengan lazimnya yang dipercaya oleh umat Islam pada umumnya. Salah satu pendapat kontroversial adalah mengenai Islam awal atau Islam klasik. Pembahasan mengenai Islam awal berarti membahas asal usul Islam dari sudut pandang ilmu sejarah dan kajian filologi klasik, orientalis masih menggunakan sumber-sumber primer Islam dalam beberapa hal, namun mereka berusaha mengelaborasi dengan catatan historis dan juga kajian kesejarahan yang tidak berlandaskan pada dogma Islam. Tokoh orientalis seperti Helmer Ringgren, D.Z.H. Baneth, M.J. Kister, John Wansbrough, Michael Cook, Patricia Crone, Montgomery Watt, Ignaz Goldziher, ${ }^{13}$ Abraham Geiger, dan lain sebagainya, adalah para akademisi Barat (orientalis) yang cukup serius mengkaji masalah Islam awal dengan segala kontroversinya. ${ }^{14}$

${ }^{12}$ Muhammad Aqil Luthfan, "Orientalisme Antara Lawan dan Kawan: Telaah Historis Transformasi Perkembangan Orientalisme, Imperialisme dan Evangelisme," Wahana Akademika 15, no. 2(2013): 135.

${ }^{13}$ Menurut M. Musthafa Azami Ignaz Goldziher merupakan orientalis pertama yang melakukan kajian di bidang hadis, lihat Idris, "Pandangan Orientalis tentang Hadis sebagai Sumber Hukum Islam," al-Thiqah 1, no. 1 (2018): 25. Pemikiran serta karyanya juga dianggap sebagai puncak orientalis dalam bidang hadis di abad ke-19, lihat Kaharuddin, dan Abdussahid, "Hadis Sebagai Sumber Hukum Islam: (Tinjauan Paham Inkar As-Sunnah, Syi'ah, dan Orientalis), Tajdid: Jurnal Pemikiran Keislaman dan Kemanusiaan 2, no. 2 (2018): 458.

${ }^{14}$ Beneth membahas Islam awal dalam salah satu artikel ilmiahnya yang berjudul “What did Muhammad Mean when He Called His Religion 'Islam'?: The Original Meaning of Aslama and its Derivatives", Helmer Ringgren dalam monografnya, "Islam, Aslama and Muslim”, M.J. Kister dalam artikel "Rajab is Month of God: A Study in Persistence of an Early Tradition", John Wanbourgh dalam buku "Quranic Studies: Sources and Method of Scriptural Interpretation", Michael Cook menulis "Muhammad", dan Michael melakukan studinya tentang Islam awal bersama dengan Patricia Crone dan menerbitkan buku "Hagarism: The Making of Islamic World", Montgomery Watt seorang ahli Islam di Barat juga menulis beberapa judul buku tentang sejarah Islam salah satunya buku yang berjudul "Muhammad at Mecca" dan "Muhammad at Medina" , Igaz Goldziher menulis buku "MuslimStudies" dan 


\section{Polemik Islam Awal: Masalah Sumber Corpus Islam Awal}

Pandangan kaum orientalis dalam ranah studi Islam cukup menarik, mereka menawarkan cara pandang yang berbeda dalam mengkaji soal Al-Quran, Hadits, sejarah Islam, dan teologi Islam. Tak jarang para akademisi Barat tersebut cenderung kritis dan skeptis pada referensi yang diakui oleh umat Islam. Corpus yang berada di tangan umat Islam, dianggap oleh mereka bukan sebagai literatur sejarah, namun sebagai literatur teologi dan ritual agama. Mun'im Sirry menjelaskan keberatan-keberatan orientalis terhadap sumbersumber Islam klasik disebabkan adanya jarak yang cukup jauh antara teks sejarah dengan kehidupan Muhammad sang nabi.

Contohnya adalah kitab sejarah tertua mengenai kelahiran Nabi Muhammad dan Islam adalah kitab Sirah Ibn Ishāq karangan Muhammad bin Ishaq bin Yasar. Walau kitab ini dalam literatur Islam dianggap sebagai kitab tertua, namun jarak antara kitab ini terbit dengan kehidupan Nabi Muhammad sejauh 100 tahun. Ini berarti antara Ibn Ishaq dengan Nabi Muhammad memiliki rentang waktu yang jauh. Dan yang lebih memusingkan, kitab Sirah Ibn Ishāq hingga saat ini tidak ditemui kecuali cuplikan tentangnya yang dikumpulkan oleh Abu Muhammad bin Abdul Malik Ibn Hisyam atau yang biasa dikenal sebagai Ibn Hisyam. Ibn Hisyam mengumpulkan data-data sejarah yang dikumpulkan oleh Ibn Ishaq yang kemudian menjadi kitab Sirah Ibn Hishām. Dan Ibn Hisyam sendiri tidak bertemu secara langsung dengan Ibn Ishaq sang penulis sejarah, namun ia mendapat cerita dan kisah-kisah tersebut melalui murid dan sahabat Ibn Ishaq yaitu Al-Bukā'̄ Al-Kūfī. ${ }^{15}$ Jarak rentang waktu yang panjang ini membuat para akademisi Barat merasa skeptis dan tidak yakin akan akurasi sejarah yang tertulis dalam sumber-sumber Islam. lalu alternatif apa yang mereka tawarkan? Para orientalis menawarkan untuk mencari sumbersumber tertulis melalui manuskrip-manuskrip sejarah yang ditulis oleh kelompok pendeta Suryani, manuskrip Yahudi, Majusi dan tulisan-tulisan sejarah yang ditulis oleh kelompok nonmuslim yang sezaman dengan rentang waktu kehidupan Nabi Muhammad dan lahirnya agama Islam.

Salah satu orang yang secara radikal menolak sumber-sumber Islam adalah Patricia Crone. Crone dengan tegas menolak sumber-sumber teks yang dihasilkan oleh sarjana Islam, bagi Crone teks-teks Islam hanyalah berisi dogma

\footnotetext{
"Introduction to Islamic Theology and Law" dan Abraham Geiger menulis buku kontroversial berjudul "Judaism and Islam". Perlu digaris bawahi bahwa teori-teori Islam awal yang dibawakan oleh para akademisi Barat ini agak kontroversial dan sebagian ada pendapat yang tidak berkesesuaian dengan pemahaman mayoritas ulama Islam. disini posisi penulis tidak sepenuhnya sependapat dengan para orientalis tersebut dan berusaha menjabarkan seobjektif dan sekritis mungkin padangan mereka.

${ }^{15}$ Ahmad Bastari, "Strategi Perang Badar menurut Ibn Hisyam dan Al-Thabari," Jurnal TAPIS 7, no.12 (2011):79.
} 
dan sakralisasi Muhammad, sedangkan secara historis tidak mampu dipertanggungjawabkan. Crone mengatakan bahwa sumber-sumber Islam terkadang tidak konsisten, contohnya kisah tentang Amr bin Ash yang datang ke Etiopia, ada riwayat yang menyebutkan Amr pergi ke Etiopia untuk berdagang, ada yang mengatakan ia datang dengan pakaian perang untuk mengeksekusi kaum Muslim yang hijrah ke Etiopia, tapi ada riwayat lain yang menyebut ia kesana untuk mengungsi. Anehnya, meski riwayat-riwayat itu berbeda-beda, namun penulisnya menjelaskan dengan begitu detail. Crone berkata: "apa yang bisa ditawarkan oleh kitab sejarah yang menerangkan begitu detail tetapi tidak ada yang akurat?". Ini yang kemudian membuatnya melihat Islam secara keseluruhan melalui teks-teks Suryani yang sezaman dengan kehidupan Muhammad. Kitab-kitab sejarah dan tarikh karya Muslim yang menceritakan tentang Islam awal biasanya adalah berisi dala' 'il nubuwah, dalil-dalil kenabian yang berfungsi untuk kepentingan dogma dan teologi Islam, guna melawan tuduhan orang-orang Kristen dan Yahudi.

Namun bukan berarti penggunaan sumber-sumber nonmuslim itu tanpa kritik dan masalah. Para penulis dari kalangan Kristen, Yahudi, Sabean, atau Majusi (Zoroaster) sebagian tentunya memandang Islam secara negatif atau malah mendistorsi berita yang sesungguhnya tentang agama Islam yang dibawa oleh Muhammad. Mengenai problem ini, Robert Hoyland dalam buku Seeing Islam as Others Saw It, menulis,

"Saya sepakat bahwa sumber-sumber nonmuslim tidak menyuguhkan penjelasan yang utuh dan koheren tentang sejarah Islam awal, apalagi untuk dijadikan sebagai sumber untuk menawarkan penjelasan alternatif tentang perkembangan agama ini. Tapi, setidaknya, dalam buku ini saya telah berhasil memperlihatkan bahwa kesaksian penulis-penulis Kristen, Yahudi dan Majusi dapat digunakan bersamaan dengan penulis-penulis Muslim untuk memberikan gambaran yang lebih kaya tentang Timur Tengah pada periode awal Islam",16

\section{Islam, Muslim dan Mu'min}

Sebagaimana yang dipahami oleh kaum Muslim pada umumnya, makna Islam dipahami sebagai penyerahan diri sepenuhnya pada Allah. ${ }^{17}$ Harun Nasution dalam buku Islam ditinjau Dari Berbagai Aspeknya, Islam adalah nama agama yang diturunkan oleh Nabi Muhammad. Islam ialah menyerahkan diri sebulat-bulatnya kepada kehendak Tuhan. Dan lewat penyerahan diri itu, manusia yang patuh dan taat pada ajaran agama Islam akan mendapat keselamatan. Islam adalah agama monoteisme yang tidak memerlukan ritual

${ }^{16}$ Mun'im Sirry, Kontroversi Islam Awal: antara Mazhab Tradisionalis dan Revisionis, (Jakarta: Mizan, 2015), 37.

17 Harun Nasution, dkk, Ensiklopedi Indonesia (Jakarta: Ichtiar Baru-Van Hoeve, 1989), 1496. 
sesaji atau pengorbanan darah apapun dalam berdoa atau untuk sarana menyenangkan Tuhan, tapi cukup menyerahkan diri sepenuh-penuhnya maka orang itu akan selamat. Dan sikap inilah menurut Harun nasution, yang membedakan dengan ajaran politeisme atau dualisme. ${ }^{18}$

Pandangan lainnya, berpendapat bahwa Islam bermakna salam atau kedamaian. Dalam bahasa Arab, Islam tersusun dari huruf sin, lam, mim ( سلم/salima) kemudian dari akar kata ini membentuk istilah سلام/salām (damai), تسليم استسلام, IIstislām (pembawa kedamaian), serta (kedamaian) اسلام ITaslìm (ketundukan, kepasrahan, dan ketenangan). Menurut Nasaruddin Umar dalam satu tulisannya, Salam adalah kedamaian dan kepasrahan dalam pengertian lebih umum. Islam adalah kedamaian dan kepasrahan dalam pengertian yang lebih khusus,. Istislam adalah seruan kedamaian dan kepasrahan yang lebih cepat, tegas, rigid, dan sempurna (perfect). Allah memberi nama agamanya yang dibawa oleh Nabi Muhammad Saw. dengan agama Islam. Bukan agama salam (kepasrahan tanpa konsep). Bukan juga agama istislam yang lebih mengutamakan kecepatan, ketegasan, dan kesempurnaan dalam memperjuangkan kedamaian dan kepasrahan. ${ }^{19}$ Dari sini, Nasaruddin Umar berpandangan bahwa Islam bermakna kedamaian yang secara konsepsional berarti Islam adalah agama yang damai, harmonis dan teratur, sebagaimana makna agama, $a=$ tidak, gama= kacau, yang berarti tidak kacau alias harmonis.

Sir. Maulana Muhammad Ali mendefinisikan Islam serupa dengan pandangan Nasaruddin Umar, bahwa Islam berarti masuk kedalam perdamaian dan orang Muslim adalah orang yang berdamai dengan Allah dan berdamai dengan manusia. berdamai dengan Allah berarti kepatuhan dan penyerahan total pada Tuhan, sedangkan damai dengan manusia adalah menghindari perbuatan sewenang-wenang dan zalim terhadap sesama manusia. ${ }^{20}$ sedangkan Sir Sayyid Amer Ali dalam buku The Spirit of Islam lebih memperluas berbagai arti kata "salama": yaitu tenang, diam, telah melakukan kewajiban, telah melunasi, dalam kedamaian sempurna, dan dari Islam berarti perdamaian, memberi salam, keamanan dan keselamatan. ${ }^{21}$

Pandangan dan pemahaman Islam diatas adalah pemahaman yang lumrah yang telah diketahui oleh banyak orang. Dalam keyakinan yang

\footnotetext{
${ }^{18}$ Harun Nasution, Islam Ditinjau dari Berbagai Aspeknya, Jilid 1, (Jakarta: UI Press, 2011), 9.

19 http://nasaruddinumar.org/meluruskan-makna-islam/, diakses pada 18 September, 2019.

${ }^{20}$ Muhammad Ali, Islamologi (Dinul Islam), terj. R. Kaelan dan Bahrun (Jakarta: Darul Kutubil Islamiyah, 2017), 4.

${ }^{21}$ Sayyid Amer Ali, The Spirit of Islam, terj. HB. Jassin (Jakarta: Pembangunan, 1967), 1.
} 
dipercayai oleh pendapat ortodox, Islam adalah kepasrahan pada Tuhan dan keselamatan bagi pemeluknya. Namun para akademisi Barat atau orientalis tidak merasa puas dengan definisi yang dirumuskan oleh para ulama dan cendekiawan Muslim. Mereka ingin menggali lebih mendalam sejarah Islam awal secara historis dan melihat jejak-jejaknya yang ada lewat penelaahan kritis teks-teks filologis tanpa tercampur oleh dogma.

Profesor Helmer Ringgern dalam buku Islam, Aslama and Muslim menjabarkan tentang makna Islam dan Muslim baik dari sudut pandang para ulama dan akademisis Muslim (yang menerima sumber-sumber ortodox ulama klasik) atau pandangan-pandangan para orientalis yang bersikap kritis (heterodox) seperti Margoliouth, Lidzbarski, Kunstingler, dan Bravmann. Teori yang dikemukakan para orientalis cukup menarik sebab mereka berpikir terlampau bebas dan menggali literatur Islam klasik tanpa ada beban moral atau tuntutan iman. Banyak pandangan yang terkesan mengada-ada namun ada pula sebagian pendapat yang masuk akal, seperti pandangan nyeleneh bahwa kata Muslim berhubungan dengan nama Musailima, sang nabi palsu, ada pula yang berpendapat bahwa kata Islam dari kata Syalom yaitu sapaan orang-orang Yahudi (syalom eleichem) yang secara teologis memiliki makna perjanjian hubungan antara Tuhan dengan manusia. Dan ada pula yang mengaitkan dengan "tantangan terhadap maut", pengorbanan diri untuk Allah dan nabinya sehingga mereka siap menantang maut. Para orientalis, sebagaimana Helmer Ringgren, dalam mengemukakan pendapat biasanya mereka mengkaji baik itu literatur Islam, Al-Quran, al-Hadits, atau sumber-sumber heterodoks seperti dari tulisan orang-orang Kristen Arab, Yahudi Arab, orang Sabean, atau dari syair-syair kuno.

D.Z.H. Baneth secara kritis menolak teori-teori pemaknaan Islam diatas. Sangat aneh bagi Baneth pandangan bahwa kata Muslim berasal dari kata Musailima yang ditolak dan dianggap sebagai nabi palsu sendiri oleh umat Islam. ia juga mengkritisi definisi Islam dalam kamus-kamus abad pertengahan dan juga tafsir-fatsir AlQuran. Bagi Baneth, kata Islam sebagai bentuk kepasrahan rohani "terlalu tinggi" untuk masyarakat Arab abad 7 yang secara spiritual amat kering dan memiliki pemahaman teologi yang sederhana dan cenderung materialistik ${ }^{22}$ dimana orang Arab jahiliyah beribadah hanya untuk keselamatan dan keuntungan duniawi tidak melihat aspek akhirat. Menurut Baneth, pemaknaan kata Islam yang berarti pasrah atau secara istilah adalah kepasrahan rohaniah secara total pada Allah, barangkali hanya cocok untuk

${ }^{22}$ Materialistik yang dimaksud oleh kami bukan materialistik dalam artian ateis atau mengacu kepada falsafat materialistik, namun masyarakat tidak memiliki konsep tentang jiwa secara utuh, alam akhirat, bahkan dibeberapa ayat menunjukan bahwa orang-orang Arab jahiliyah tidak percaya pada adanya kebangkitan. 
suatu komunitas masyarakat yang sangat maju baik pemikiran falsafinya atau pemahaman spiritualnya. Baneth berpendapat, apalah arti seorang Nabi menjelaskan pada masyarakat yang masih primitif, budak-budak, kaum miskin, dan suku-suku yang berhati keras tentang "penyerahan diri kepada Tuhan". Padahal tanpa diperintahpun masyarakat Arab jahiliyah sudah berpasrah pada dewa-dewa mereka (dengan pemahaman teologi yang sederhana).

Baneth menjelaskan bahwa arti Islam yang dibawakan oleh Nabi Muhammad tak lepas dari tujuan dari agama yang dibawa oleh Muhammad, yaitu meninggalkan politheisme dan juga sikap syirik. Walaupun (mungkin) kata Islam juga memiliki makna penyerahan sebagaimana dalam penafsiran para ulama Islam, namun kata Islam menurut Baneth dimasa awal tidak berhubungan dengan kepasrahan, tetapi lebih kepada kontra terhadap kemusyrikan. Kata Islam saat itu sebagai kata yang digunakan sebagai antonim dari syirk. Syirk sendiri berarti orang-orang yang menyekutukan Allah dengan tuhan-tuhan lain. Sebab masyarakat Arab jahiliyah, selain mereka meyakini Tuhan Allah, mereka juga meyakini adanya tuhan-tuhan lain sebagai sekutu Allah. Konsepsi politheisme yang membangun persekutuan antara Allah dengan tuhan-tuhan palsu itu melahirkan istilah-istilah seperti ashraka, shirk, mushrik. Sehingga kata Islam mencerminkan ide yang berlawanan.

Secara konkrit, Baneth menjelaskan makna Islam atau salam menurut pemahaman Al-Quran dalam surat Az-Zumar ayat 29:

"Allah membuat perumpamaan (yaitu) seorang laki-laki (budak) yang dimiliki oleh beberapa orang yang berserikat yang dalam perselisihan dan seorang budak yang menjadi milik penuh (salaman) dari seorang laki-laki (saja); Adakah kedua budak itu sama halnya? Segala puji bagi Allah tetapi kebanyakan mereka tidak mengetahui"

Di sini, di dalam bagian akhir masa Mekah atau awal masa Madinah, masyarakat Arab memiliki sepatah kata dari akar $s l m$, yang jelas dan tegas artinya "hanya semata-mata milik yang satu belaka" atau "semata-mata milik yang satu", yang membedakan suatu benda atau manusia yang milk orang-orang atau sekutu. Ayat Az Zumar ini membahas tentang tauhid atau tentang perbedaan antara orang musyrik dan orang Muslim. Dari sini Baneth berpandangan bahwa Islam memiliki arti "milik Tuhan yang satu" atau "sematamata hanya mengabdi pada Tuhan Allah saja". Arti ini secara sederhana mengungkapkan bahwa Islam yang dibawa oleh Nabi Muhammad adalah lawan langsung dari kemusyrikan yang menyekutukan Allah dengan banyak dewa- 
dewa, bukan bermakna kepasrahan rohani sebagaimana pandangan ulama dan akademisi Islam lainnya..$^{23}$

Jika Baneth mencoba merekonstruksi pemaknaan kata Islam dan salama, dengan melihat dari sumber-sumber Muslim pada umumnya, sikap ini berbeda dengan orientalis seperti Fred Donner yang mencoba bersikap agak kritis dalam merekonstruksi kata Islam dan muslim. Para orientalis yang kritis, bertumpu pada sosiologi agama, bahwa agama tidak muncul dalam sekejap mata, tetapi merupakan proses sosial dan berkembang (berevolusi) secara bertahap. Jikalau Umat Islam pada umumnya menganggap Islam adalah nama dari agama yang diturunkan pada Nabi Muhammad dan telah sempurna ketika Muhammad meninggal, para orientalis tidak sepakat dengan pendapat demikian. Agama sebagai suatu produk dari kebudayaan manusia tak lepas dari evolusi dan perkembangan. Dalam hal ini Fred Donner berusaha untuk menggali istilah penggunaan nama Islam, $\mathrm{Mu}$ 'min dan Muslim dengan dasar teori evolusi agama.

Fred Donner menganggap bahwa kata mukmin dan muslim memiliki perbedaan. Muslim dalam Al-Quran disebut muncul hanya tujuh puluh lima kali dalam Al-Quran, sedangkan Mukmin hampir 1000 kali diucapkan. Donner berpendapat istilah mukmin adalah sebuah komunitas yang dirintis oleh Muhammad, sebuah komunitas yang berpaham monoteistik dan hanya menyembah satu Tuhan: Allah. Pada awalnya istilah Mukmin ini bersifat cair, orang-orang yang secara fundamental mengakui bahwa Tuhan itu satu dan meyakini hari akhirat maka itu adalah seorang mukmin. Ini berarti komunitas mukmin bersikap inklusif, dimana komunitas yang berpaham monoteistik juga disebut mukmin, termasuk kelompok Kristen dan Yahudi.

Donner ingin mendeskripsikan bahwa pada mulanya komunitas pengikut Muhammad belumlah menjadi suatu komunitas institusi yang mapan yang disebut Islam. Dalam kitab Tarikh Ya'qubi, ketika orang-orang musyrik bertanya pada Muhammad tentang agamanya, ia menjawab bahwa agamanya adalah agama Ibrahim, ini menunjukan bahwa komunitas Islam awal belum menamakan diri mereka sebagai seorang Muslim atau Islam, Donner menyebut komunitas monoteistik ini sebagai mukmin. Salah satu ayat yang menjadi rujukan Donner adalah surah Al-Baqarah ayat 62 dan Al-Maidah ayat 69, yaitu "Sesungguhnya (mereka) orang-orang beriman, orang-orang Yahudi, orangorang Nasrani dan orang-orang Shabiin, siapa saja diantara mereka yang benar-benar beriman kepada Allah, hari kemudian dan beramal saleh, mereka akan menerima pahala dari Tuhan mereka, tidak ada kekhawatiran kepada

${ }^{23}$ H.L. Beck dan N.J.G. Kaptein, Pandangan Barat terhadap Islam Lama, terj. Sukarsi (Jakarta: INIS, 1989), 4-6. 
mereka, dan tidak (pula) mereka bersedih hati" dalam ayat ini, menggambarkan kesederajatan kelompok mukmin bahwa mereka yang menyembah satu Tuhan (monoteistik) akan mendapat keselamatan juga. Selain itu Donner membawa teks Piagam Madinah bahwa orang-orang Yahudi dari Bani Auf adalah satu umat (ummatan wahidah) dengan kaum mukmin" teks piagam ini merupakan bentuk inklusifitas ajaran dari Muhammad.

Dokumen dari kaum Yahudi dan Kristen di Syria juga menunjukan bahwa kaum kelompok pengikut Muhammad disebut sebagai kaum mukmin dan bukan Muslim, ini ditunjukan dengan para khalifah atau penguasa Islam yang berjuluk Amir al-mu 'minin. Pergeseran kata mukmin menjadi Muslim terjadi ketika komunitas mukmin sudah merasa kuat dan memiliki identitas yang independen dari komunitas lain seperti Yahudi dan Nasrani, sehingga Khalifah Abdul Malik bin Marwan menjadikan kata Muslim sebagai identitas pemisah antara penganut agama monoteistik lainnya, yaitu Yahudi dan Kristen. Khalifah Abdul Malik bin Marwan yang mengklaim sebagai "Khalifah Allah" melakukan berbagai macam ekspansi baik ke wilayah Romawi Bizantium hingga ke tanah India. Ekspansi ini membuat komunitas orang-orang beriman mulai "renggang" sehingga Abdul Malik bin Marwan menggunakan istilah baru untuk menamakan komunitas monoteis yang mengakui kenabian Muhammad dan kitabsuci Al-Quran yaitu Islam dan Muslim sebagai pembeda yang tegas dengan kelompok mukmin Yahudi dan Kristen. ${ }^{24}$

\section{Muhammad dan Al-Quran}

Selain mencoba meneliti penggunaan istilah Muslim, Islam dan Mukmin dimasa awal Islam, para orientalis juga mengkaji asal-usul Islam juga dari kacamata semantik dan teologis. Seperti Abraham Geiger, salah satu tokoh akademisi Barat berdarah Yahudi yang meneliti tentang Islam dan membandingkannya dengan agama Yahudi. Bagi Geiger, Islam bukan agama baru atau turun dari sebuah wahyu, tetapi ia muncul sebagai dari seorang yang mengikuti Yahudi kemudian membuat sekte baru yang menyimpang dari agama Yahudi. Sebagai sebuah agama awal dalam tradisi semitik, Geiger berpandangan bahwa agama Yahudi memiliki otoritas yang lebih tinggi dan berhak menilai agama lain seperti Kristen dan Islam. dan agama-agama tersebut bagi Geiger adalah salah satu bentuk agama yang menyimpang dari agama Yahudi. ${ }^{25}$

Abraham Geiger sebenarnya berkonsentrasi pada studi kitab suci, antara Torah dengan Al-Quran, namun sedikit banyak Geiger menerangkan tentang

\footnotetext{
${ }^{24}$ Mun'im Sirry, Kontroversi Islam Awal: antara Mazhab Tradisionalis dan Revisionis, 121-126.

${ }^{25}$ M. Anwar Syarifuddin, Kajian Orientalis terhadap Al-Quran dan Hadis (Jakarta: UIN, 2012), 37.
} 
banyaknya ajaran-ajaran Yahudi dan alkitab yang "jiplak" oleh Al-Quran, ini berarti Geiger menganggap bahwa sejarah Islam, sedikit banyak, memiliki hubungan genealogis dengan agama Yahudi. Dalam Al-Quran, terdapat 14 kosakata yang bisa dikatakan menjiplak dari kosakata bangsa Yahudi, yang mana kosakata tersebut tidak dimiliki dan asing dalam masyarakat Arab pra Islam, seperti sakinah, taaghut, furqan, ma'un, masani, malakut, darasa, tabut, jannatu adn,taurat, jahannam, rabbani, sabt, dan ahbar.

Dari segi doktrin, menurut Geiger banyak doktrin-doktrin Islam yang sangat mirip dengan Agama Yahudi, ini membuktikan bahwa Muhammad sedikit banyak terpengaruh oleh ajaran Yahudi dalam membentuk dogma agamanya. Yang pertama adalah doktrin penciptaan. Dalam Quran, penciptaan bumi dan langit selama 6 masa, ini sesuai dengan doktrin Torah dalam Syefer Beresyith atau kitab Kejadian yang menulis tentang 6 hari masa penciptaan bumi dan langit. Namun Muhammad tidak mengambil hari ketujuh sabt sebagai hari sakral sebagaimana yang tertera dalam Torah (Tanakh) disebabkan Muhammad mengkuduskan hari Jumat sebagai hari ibadah, bukan sabt (sabtu) agar terlihat berbeda dari Yahudi.

Kemudian doktrin tujuh tingkatan Surga yang sangat mirip dengan kepercayaan Yahudi, yang tertera dalam Chagiga 9:2 serupa dengan Al-Quran surah Al-baqarah ayat 29. Kepercayaan terhadap hari akhirat dalam Islam sangat mirip dengan Yahudi, ketimbang Nasrani. Doktrin tentang neraka Jahannam juga dikenal dalam agama Yahudi, malah Geiger menganggap kosakata jahannam diambil dari kata gehinnom yang tertera dalam kitab Talmud. Begitu juga tentang surga Jannatul adn yang tertera dalam Al-Quran, serupa dengan taman Eden yang tertera dalam Tanakh. Dari sini Geiger seolah berpendapat bahwa agama Islam pada hakikatnya adalah salah satu sempalan dalam agama Yahudi. Dimana Muhammad tentu seorang terpelajar yang memahami agama Yahudi dan melakukan studi terhadap naskah-naskah rabbinik sehingga ia membuat agama baru yaitu Islam.

Teori bahwa agama Islam berasal dari agama Yahudi juga dikemukakan oleh Patricia Crone dan Michael Cook. Sebagaimana yang dijelaskan diatas, Crone menolak sumber-sumber Islam dan beralih ke teks-teks Suryani. Dan kesimpulannya ia menemukan tentang Hagarisme. Muhammad diasosiasikan sebagai kelompok Yudeo-Hagarism yaitu seorang Yahudi dari keturunan Bani Hajar (keturunan Ismail) yang berdomisili di kawasan Hijaz. Mereka disebut sebagai Mhaggraye yang kemudian ditanslitrasikan menjadi "muhajirin". Dan Muhammad adalah seorang tokoh Yahudi Hagarian yang mempunyai pandangan Mesianik untuk merebut kota Yarusalem yang direbut oleh Kristen Bizantium. Kemudian ia mengonsolidasikan kekuatannya di Madinah. Muhammad dianggap Patricia sebagaimana Yahya pembaptis yang 
mempersiapkan kedatangan Isa (Yesus), Muhammad mengonfirmasikan akan kedatangan sang Mesias yang akan merebut kota Yarussalem, yaitu Al-Faruq, Umar bin Khathtab.

Setelah kaum Hagarisme menguasai Palestina, mereka takut akan terjadi percampuran antara mereka dengan ajaran Yudaisme, sehingga mereka, menurut Crone, mengambil sikap yang politis, seperti berdamai dengan kelompok Kristen dengan mengakui dan menghormati Isa (walau mereka menolak ketuhanan dan penyaliban Isa) dan kemudian mereka membuat tanah suci lain selain Yarussalem. Jika Kaum Samaria mempunyai tanah suci di Sikhem dan Gunung Gerizim, maka mereka menjadikan Mekkah sebagai kota suci dan Ka'bah sebagai bait sucinya. Kemudian mereka mengumpulkan tulisan-tulisan Muhammad yang kemudian menjadi Al-Quran dan disempurnakan di zaman Abdul Malik bin Marwan oleh Gubernur hajaj ibn Yusuf. ${ }^{26}$

Padangan Patricia Crone tentang Muhammad dan misinya tentang Islam sangat berseberangan sama sekali dengan pemahaman akademisi Islam dan karya-karya sejarawan lampau Islam. Crone sendiri sedikit banyak terpengaruh oleh John Wansborgh. Dimana Wansborgh mempunyai pandangan bahwa AlQuran yang menjadi sumber Islam nomor satu tidak turun di Mekkah dan Madinah, tetapi di Iraq atau Mesopotamia. Argumen Wansborgh tentang AlQuran ini berdasarkan asumsi Wansbourgh bahwa teks Al-Quran sangat modern dan ia turun di masyarakat yang pluralis. Dan Iraq sangat cocok ketimbang Mekkah dan Madinah. Wansborgh juga meyakini bahwa Quran dikumpulkan pada masa Khalifah Abdul Malik bin Marwan, bukan zaman Abu Bakar. Tentu pandangan John Wansbourgh ini sangat bertentangan dengan keyakinan Muslim tradisional pada umumnya tentang awal mula kemunculan Al-Quran.

\section{Mengkritisi Pandangan Orientalis tentang Islam Awal}

Membaca hasil penelitian dan catatan yang ditulis oleh para akademisi Barat yang konsen pada studi Islam, sebagaimana yang kami paparkan diatas, tentu terdengar sangat asing, aneh, bahkan cukup "menganggu" keimanan dan keyakinan seorang Muslim yang begitu membanggakan dan mensakralkan agamanya. Namun sekali lagi, sekeras dan senyeleneh apapun. tujuan dasar dari orientalis barat bukan untuk menghancurkan Islam atau berkonspirasi untuk melenyapkan Islam, tetapi murni sebagai kajian akademis walaupun didalamnya banyak penyimpangan dan distorsi pemahaman dari keyakinan Islam dan sumber-sumber kredibel yang diyakini oleh umat Islam.

Perlu digarisbawahi, bahwa hasil-hasil penelitian dari para orientalis tidak secara mutlak harus diterima, sebagaimana tidak ada kebenaran mutlak

${ }^{26}$ https://en.wikipedia.org/wiki/Hagarism diakses 19/09/2018 pukul 17:45 WIB 
dalam ilmu pengetahuan modern. pandangan-pandangan kaum orientalis hanya sekedar sebagai alat pembanding dan bahan refleksi pribadi supaya kita dapat memahami Islam tidak berat sebelah. Sebagaimana dalam studi sejarah yang diterangkan oleh Morton White, ilmu sejarah hanya menyajikan kebenaran yang bersifat relatif, tidak ada hukum mutlak didalamnya. Jika kita kaitkan ucapan Morton ini dengan pandangan Crone, Donner, Wansbourgh mengenai sejarah Islam awal tetap saja kajian mereka bersifat relatif atau opini, meskipun mereka berdasarkan pada teks-teks Suryani manuskrip-manuskrip tua, tetap saja hasil kajian mereka tak lepas dari perspektif subjektif alias penafsiran mereka terhadap bukti-bukti sejarah.

Dalam studi Hermeneutik, pembacaan seseorang terhadap suatu teks tak lepas dari verstehen (pemahaman) orang tersebut jadi merekonstruksi sejarah menjadi sebuah peristiwa yang utuh dengan cara mengumpulkan kepingankepingan terpisah, bisa dikatakan sangat sulit, kompleks, dan tak lepas dari pandangan subjektif si histografer. Sebagaimana kata Nietzsche, bahwa tidak ada peristiwa faktual kecuali hanya interpretasi. Karena itu pandangan para orientalis terhadap Islam awal tidak berisi kebenaran sepenuhnya.

Hal yang sangat disayangkan oleh penulis, sikap kaum orientalis yang terlampau ekstrim dalam menerima teks-teks Islam sebagai suatu sumber sejarah. Anggapan bahwa semua sumber historis Islam adalah palsu sebagaimana yang dikemukakan oleh Crone, terlampau gegabah. Banyak faktafakta historis yang dicatat dalam kitab-kitab tarikh Islam yang sesuai dengan naskah-naskah yang ada ditangan kaum Kristen Arab, seperti pengakuan M.J. de Goeje yang membandingkan peristiwa-peristiwa dalam kitab Sirah Ibn Ishāq dengan sumber-sumber Kristen yang ditulis dalam bahasa Suryani dan Yunani. Hasilnya, banyak fakta-fakta sejarah dalam kitab Sirah yang akurat dan sesuai, seperti kisah tentang penakhlukan Suriah (Byzantium) ${ }^{27}$. Ini menunjukan bahwa teks-teks sejarah Islam tidak sepenuhnya palsu atau hanya berisi dogma tentang Islam dan Muhammad.

Pandangan Wansbourgh bahwa Al-Quran muncul di Iraq hanya karena ketiadaan Al-Quran dimasa Nabi Muhammad, kecuali Quran yang ada pada masa Bani Umayyah merupakan prasangka subjektif. Begitu juga kritik Crone tentang banyaknya data-data yang berbeda-beda dalam sejarah Islam menunjukan ketidaktahuan keduanya, bahwa tradisi sejarah Islam awal bukanlah seperti dalam Kristen dan Yahudi. Sumber historis Islam adalah sumber verbal bukan tekstual. Karena itulah dalam Islam terdapat istilah isnad dan rawi yang menunjukan bahwa sejarah Islam bersumber dari tradisi pengajaran lisan. Agar

${ }^{27}$ Mun'im Sirry, Kontroversi Islam Awal: antara Mazhab Tradisionalis dan Revisionis, 44. 
sumber lisan itu tetap akurat dan (minimal) tidak terjadi banyak kesalahan, maka para ulama melakukan studi kritik sanad dengan mengembangkan ilmu rijāl dan jarh wa al-ta'dìl. Disini penulis berpendapat bahwa para orientalis yang skeptis pada sumber Islam justru tidak memahami tradisi kesejarahan dalam dunia Islam secara mendalam.

Teori Baneth tentang arti dari nama "Islam" yang menurutnya sebagai "kepatuhan semata-mata hanya pada satu Tuhan" mungkin masih bisa diterima. Namun penolakannya pada arti "penyerahan rohani" pada kata taslim (Islam) dengan dalih bahwa masyarakat Arab terlampau primitif untuk memahami makna itu, sangat tidak masuk akal. Sejarawan Islam modern seperti Dr. Haekal Muhammad menerangkan bahwa Mekkah adalah kota metropolitan tempat singgahnya para kafilah-kafilah dagang dari berbagai penjuru, seperti Yaman, Hira, Syam, Najd dan lokasinya yang dekat laut Merah adalah bukti bahwa Mekkah adalah kota bisnis dengan jaringan internasional bahkan telah menjalin hubungan dengan kafilah pedagang dari China. Sungguh sangat tidak masuk akal jika Mekkah dianggap kota primitif dan masyarakatnya terbelakang sebagaimana anggapan Baneth. ${ }^{28}$

Begitu juga anggapan Fred Donner tentang istilah Islam dan Muslim yang baru digunakan ketika Khalifah Abdul Malik bin Marwan berkuasa, juga tidak sesuai fakta yang tertulis dalam Al-Quran sendiri, yaitu Surah Al-Maidah ayat 3 "Ku cukupkan kepadamu nikmat-Ku, dan telah Ku ridhai Islam itu jadi agama bagimu." Ayat ini menunjukan bahwa Islam sudah digunakan sedari awal sebagai suatu nama agama untuk komunitas monoteis yang meyakini kerasulan Muhammad.

\section{Kesimpulan}

Secara historis, realitas pengkajian Barat terhadap Islam memang pada mulanya sebagai penopang imperialisme dan kolonialisme Barat. Namun seiring hilangnya kolonialisme, para orientalis menjadi independen dan tidak lagi terjebak oleh paradigma politis dan kepentingan dalam mengkaji Timur, khususnya studi Islam. salah satu kajian yang ditelusuri oleh para orientalis adalah mengenai eksistensi Islam awal. Islam awal atau Islam lama berarti kajian sejarah mengenai asal mula agama Islam dan bagaimana kemunculan agama Islam. Mengkaji kembali sejarah Islam awal memang bisa dikatakan cukup menarik, Apalagi jika terdapat bukti-bukti baru yang hangat untuk dikaji.

Para oientalis seperti Patricia Crone, Wansbourgh, Fred Donner, dan Abraham Geiger mengemukakan teori Islam awal yang cukup kontroversial dan

${ }^{28}$ Haelkal Muhammad, Sejarah Hidup Muhammad, terj. Ali Audah (Jakarta: Pustaka Jaya, 1982), 36. 
bertentangan dengan sumber sejarah yang diyakini oleh umat Islam. Namun sebagaimana suatu kajian sejarah, suatu teori atau hipotesis yang dikemukakan oleh para orientalis (sekontroversi apapun) tetaplah merupakan penafsiran subjektif daripada si pengamat. Sejarah begitu kompleks dan rumit, sebagaimana pandangan Mohammed A. Bamyeh, Guru Besar di macelester College, bahwa bukti-bukti arkeologis dan filologis dari para orientalis yang mengkaji sejarah Islam awal masih terlampau sedikit untuk merekonstruksi suatu peristiwa utuh yang sebenarnya. Karena banyaknya lubang-lubang kosong dari data-data yang dimiliki oleh para orientalis, akhinya rekonstruksi sejarah yang mereka lakukan justru malah kerap diisi oleh pemikiran liar dan hayalan konspirasi.

\section{Daftar Pustaka}

Akkase, Muhammad Bahar. "Orientalis dan Orientalisme Dalam Perspektif Sejarah,." Jurnal Ilmu Budaya 4, no.1 (2016).

Ali, Lukman. Kamus Besar Bahasa Indonesia (KBBI) Edisi Kedua. Jakarta: Departemen Pendidikan dan Kebudayaan Balai Pustaka, 1993.

Ali, Muhammad. Islamologi (Dinul Islam),terj. R. Kaelan dan Bahrun. Jakarta: Darul Kutubil Islamiyah, 2017.

Ali, Sayyid Amer. The Spirit of Islam, terj. HB. Jassin. Jakarta: Pembangunan, 1967.

Bastari, Ahmad. "Strategi Perang Badar menurut Ibn Hisyam dan Al-Thabari." Jurnal TAPIS 7, no. 12 (2011).

Beck, H.L. dan N.J.G. Kaptein, Pandangan Barat terhadap Islam Lama, terj. Sukarsi. Jakarta: INIS, 1989.

Idris. "Pandangan Orientalis tentang Hadis sebagai Sumber Hukum Islam." alThiqah 1, no. 1 (2018).

Kaharuddin, dan Abdussahid. "Hadis Sebagai Sumber Hukum Islam: (Tinjauan Paham Inkar As-Sunnah, Syi'ah, dan Orientalis)." Tajdid: Jurnal Pemikiran Keislaman dan Kemanusiaan 2, no. 2 (2018).

Khaldun, Rendra. "Telaah Historis Perkembangan Orientalisme Abad XVIXX.” Jurnal Ulumuna 11, no. 1 (2007).

Luthfan, Muhammad Aqil. "Orientalisme Antara Lawan dan Kawan: Telaah Historis Transformasi Perkembangan Orientalisme, Imperialisme dan Evangelisme." Wahana Akademika 15, no. 2 (2013).

Al-Makin, Antara Barat dan Timur: Batasan, Dominasi, Relasi, dan Globalisasi. Jakarta: Serambi: 2015.

Muhammad, Haelkal. Sejarah Hidup Muhammad, terj. Ali Audah. Jakarta: Pustaka Jaya, 1982.

Al-Muhasib, Abdul Majid Abdussalam. Visi dan Paradigma Al-Qur 'an Kontemporer, terj. M. Maghfur Wachid. Bangil: Al-Izzah, 1997. 
Nasution, Harun, dkk. Ensiklopedi Indonesia. Jakarta: Ichtiar Baru-Van Hoeve, 1989.

Nasution, Harun. Islam Ditinjau dari Berbagai Aspeknya, Jilid 1. Jakarta: UI Press, 2011.

Nuurachman, Dian, dan Rohanda. "Orientalisme vs Oksidentalisme: Benturan dan Dialogisme Budaya Global." Jurnal Lektur Keagamaan 15, no. 2 (2017).

Said, Hasani Ahmad. "Potret Studi al-Qur'an di Mata Orientalis." Jurnal AtTibyan 3, no. 1 (2018).

Sirry, Mun'im. Kontroversi Islam Awal: antara Mazhab Tradisionalis dan Revisionis. Jakarta: Mizan, 2015.

Susmihara. "Sejarah Perkembangan Orientalis." Jurnal Rihlah 5, no. 1 (2017).

Syarifuddin, M. Anwar. Kajian Orientalis terhadap Al-Quran dan Hadis. Jakarta: UIN, 2012. 